\title{
Born in Brazil: shining a light for change
}

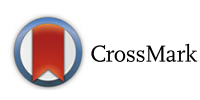

\author{
Maria Regina Torloni ${ }^{*}$, Ana Pilar Betrán ${ }^{2}$ and José M. Belizán ${ }^{3}$
}

\begin{abstract}
The Birth in Brazil study is the largest national hospital-based survey in Brazil regarding birth practices. Conducted in 2011-2012, it collected information from 266 public and private healthcare facilities and interviewed nearly 24,000 postpartum women. It is also the latest effort to map out how labor and delivery are managed in this county in the 21 st century. The journal Reproductive Health has published a supplement including 10 articles presenting the results of a series of analyses using this valuable resource.

These articles describe a range of practices, determinants and risk factors that affect women and their babies in Brazil, a country of paradoxes. In the era of overmedicalization and high-tech medicine - arguably -, these articles highlight the unprecedented rates of cesarean sections in Brazil and differences between the public and the private sectors. It provides evidence for the need for adequate human resources, medications and emergency care equipment in many settings; and explains the use of non-evidence based interventions during labor and delivery. On the other hand, these studies also point to promising interventions that could be used to change this situation not only in Brazil but also in other countries facing similar challenges.
\end{abstract}

Brazil, one of the largest country in the world in terms of territory and population, has many socioeconomic contrasts and paradoxes. There are large disparities in the obstetric care received by women in the highest socioeconomic strata, mainly managed by private health insurance, compared to those in the lowest strata who are fully dependent on the often deficient and overburdened free public health system. In this Supplement, $R e-$ productive Health publishes a series of articles that describe what is happening in Brazil in relation to birth practices, their consequences and potential ideas for interventions that could help to change this picture.

The studies in this issue used data from the largest national hospital-based survey (the "Birth in Brazil" study) which collected information from 266 public and private healthcare facilities and interviewed nearly 24,000 postpartum women between 2011-2012 [1]. This landmark study, coordinated by Maria do Carmo Leal from Osvaldo Cruz Foundation (Fiocruz) in collaboration with several prestigious Brazilian scientific institutions, mapped out and synthesized for the first time the situation about birth practices in the county in the $21^{\text {st }}$ century. The many highly informative publications from this

\footnotetext{
* Correspondence: ginecologia@terra.com.br

${ }^{1}$ Department of Internal Medicine, Evidence Based Healthcare Post-Graduate

Programme, São Paulo Federal University, São Paulo, Brazil

Full list of author information is available at the end of the article
}

laborious and carefully conducted study provide a revealing picture of how labor and delivery are currently managed in the country and offer insightful data on the determinants, magnitude and consequences of the use of interventions during labor and delivery in Brazil. More importantly, these studies also point to possible ideas, actions and interventions to improve obstetric care in the country.

One of the most striking characteristics of Brazil is the high rates of cesarean deliveries (CD), especially in the private sector, where $80-90 \%$ of all women are delivered by this route [2,3]. Despite the lack of evidence indicating substantial health benefits of $\mathrm{CD}$ rates beyond a certain threshold, and growing evidence that $\mathrm{CD}$ may be associated with poorer maternal, neonatal, childhood and long term outcomes [4-9], the use of this surgery has steadily increased over the last thirty years in most high and middle-income countries [10]. According to official national estimates, Brazilian $\mathrm{CD}$ rates rose from $38 \%$ in 1994 to $50 \%$ in 2009 and reached $57 \%$ in 2015 $[3,10]$. This means that each year, nearly $1,700,000$ caesareans are performed in Brazil, many of which are probably unnecessary from a medical perspective $[11,12]$.

Indeed, the probability of having a $\mathrm{CD}$ in Brazil is heavily influenced by non-medical factors. Brazilian women who have more education, are in their first pregnancy and who receive prenatal care in the private 
sector have a significantly higher probability of delivering by cesarean section (C-section) than those without these characteristics [11, 13-16]. The study by Gama and Nakamura-Pereira et al. [17] reports that while $52 \%$ of all women interviewed in the national survey delivered by cesarean, CD rates were $88 \%$ in the private hospitals compared to $43 \%$ in the public hospitals. Moreover, as reported in a previous publication using the same dataset, $80 \%$ of the $\mathrm{C}$-sections in the private sector were electively scheduled and performed before the onset of labor [18]. Gama and Nakamura-Pereira et al. also analyzed the data using the Robson classification and report that nulliparous women in spontaneous labor at term, with a singleton cephalic fetus (Robson group 1) delivered in private hospitals had more than twice the rate of $C D$ than in public hospitals ( $44 \%$ versus $18 \%$, respectively) [17]. These results suggest that clinical practice varies enormously in different settings in Brazil and may be heavily influenced by societal and other nonmedical factors. Although the rates of $\mathrm{CD}$ in nulliparas are much lower in the public than in the private sector, they are still considerably higher than what would be considered medically reasonable. However, as Dias et al. [19] report, this could be improved with the adoption of simple interventions. In their analysis of nulliparous women delivering in public hospitals, these authors concluded that information and support for vaginal birth during antenatal care, avoiding early admission (before $4 \mathrm{~cm}$ dilation), and promoting the use of good clinical practices during labor could reduce unnecessary $\mathrm{CD}$ in nulliparous women with a singleton cephalic fetus.

$\mathrm{C}$-sections are perceived by some women as safer than vaginal deliveries [20-24]. This misconception may be a potential contributor to the high rates of scheduled Csections in Brazil, especially maternal-request cesareans performed in the private sector. However, as previously reported in other studies, and contrary to popular belief, elective C-sections are not without risk [8, 25-29]. In one of the articles of this issue, Domingues et al. show that women with an elective C-section had over twice the risk of maternal near miss, after adjustment for pregnancy complications, social and demographic variables, and antenatal care [30]. The increased risk for maternal near miss in women submitted to elective $\mathrm{C}$-sections in Brazil is especially worrisome when we look at the findings of Bittencourt et al. that show the low quality of hospital services available for pregnant women [31]. According to these authors, less than $35 \%$ of the maternity wards across the country have adequate human resources, medications and emergency care equipment to ensure survival and adult intensive care beds. These findings underscore the need to avoid unnecessary CD in Brazil, especially in settings that lack the facilities and/or capacity to properly conduct safe surgery and treat surgical complications, as recommended by the 2015 WHO Statement on Caesarean Section Rates [9]. In addition, the Birth in Brazil study reported that the rate of preterm births (PTB) in the 2011-2012 survey was $11.5 \%$ [32] which is nearly twice that of European countries [33, 34]. Leal et al. conclude that the high rate of PTB in Brazil is due to a high proportion of providerinitiated late preterm births, especially among women being delivered in private healthcare facilities and those with a previous $C D$ [32]. This suggests that many cases of late PTB in Brazil may be caused by iatrogenic prematurity in women scheduled for elective $\mathrm{CD}$, with incorrect gestational age assessment. The practice of delivering late preterm infants is associated with increased morbidity, including the need for resuscitation in the delivery room, as pointed out by the study by Moreira et al. [35].

The aim of care during normal labor is to achieve a healthy mother and child with the least possible level of intervention that is compatible with safety. Since women and their babies can be harmed by unnecessary practices, there should be a valid reason to interfere with the natural birth process [36]. In Brazil, the use of nonevidence based interventions during labor and delivery (e.g. routine episiotomy or oxytocin drips) is still high, while the adoption of beneficial, evidence-based practices (i.e. partographs) is still low. In fact, best practices during labor were adopted in less than half of all women delivered in the Birth in Brazil study [37]. However, da Gamma et al. point to a solution for this situation: include more nurse-midwives in the healthcare teams. These authors report that in Brazilian settings where a nurse-midwife was in charge of conducting labor and delivery, the use of good practices recommended by WHO was significantly more frequent, and the use of obstetric interventions was significantly less frequent, than in settings where labor and delivery were conducted exclusively by physicians [38]. Moreover, the study also concluded that the presence of a nurse-midwife in the maternity care team reduced the rate of $\mathrm{CD}$, a finding confirmed by another Brazilian study involving private hospitals [39]. In addition, basic human and social skills are also important for health professionals caring for women in labor. In fact, good communication and a respectful, supporting and empathic relationship between the healthcare providers and laboring women are part of the good clinical practices promoted by WHO ever since 1996 [36]. Baldisserotto et al. reported that this type of communication, along with the presence of a birth companion throughout labor and delivery, were associated with increased satisfaction of Brazilian women with the care received during childbirth [40]. A recent WHO statement emphasizes the importance of providing respectful care for laboring women [41]. 
Being born vaginally increases the success of breastfeeding practices, an essential aspect of maternal and infant health. The benefits of breastfeeding during the initial years of life cannot be overstated. Early suckling stimulates breast milk production and facilitates the release of oxytocin, which helps the uterus contract reducing postpartum blood loss. The colostrum contained in the first breast milk is highly nutritious and has antibodies that protect the newborn. Early initiation of breastfeeding also fosters bonding between mother and child. In the Birth in Brazil study, babies born vaginally had almost three times the chance of being breastfed in the first hour after birth than those born by C-section [42].

Paradoxically, the urge of Brazilians to plan and control how and when to deliver, that can be inferred from the high elective CS rates in the national survey, does not seem to run in parallel with the need to plan if and when they want to get pregnant. According to Theme et al., less than $45 \%$ of the post-partum women interviewed in the national survey reported that their pregnancy had been intended [43]. Worldwide, it is estimated that approximately $40 \%$ of all pregnancies are unintended, ranging from $35 \%$ in Africa to $56 \%$ in Latin America and the Caribbean region [44]. The findings of Theme et al. point to the need to implement strategies to overcome barriers and increase the access to high quality of family planning services in Brazil.

The series of studies in this issue Reproductive Health point to the paradox of obstetric care in Brazil and its consequences, in other words: overmedicalization of childbirth, alongside with substandard quality of care, leading to potentially avoidable adverse maternal and neonatal outcomes. This situation can change if policy makers, stakeholders, physicians, nurses, midwives and women in Brazil join forces and take action. The findings of the studies reported in this Reproductive Health issue also serve as a warning to what may (or will soon) be happening in other middle-income countries, if nothing is done to halt and reverse the increasing CD trend. On the other hand, these studies also point to promising, and often simple and low-cost, interventions that could be used to change this situation in Brazil and in other countries facing similar challenges.

Kant said: "Dare to know". This is what the Birth in Brazil study set out to achieve by taking a closer and evidence-based look at what it is happening in their country. The aim of the studies published in this Reproductive Health supplement, as well as the aim of this editorial, is not to criticize health authorities, healthcare providers or women but to raise awareness about a system that does not always seem to have the "best care for the woman and baby' as its primary goal. Knowledge is a double edge sword; it saves us but also burdens us with the responsibility for action. More research is now needed to move beyond describing problems and barriers, to identify and test solutions. However, work will be slow and intense since changes, especially sustainable changes, do not occur overnight. Long-held societal and cultural routines, practices, views and beliefs are never easy to put aside, but we are confident that Brazil is reaching a critical mass of awareness, knowledge and will to improve obstetric care.

\section{Authors' contributions}

All authors read and approved the final manuscript.

\section{Competing interests}

The authors declare they have no competing interests.

\section{Author details}

${ }^{1}$ Department of Internal Medicine, Evidence Based Healthcare Post-Graduate Programme, São Paulo Federal University, São Paulo, Brazil. ${ }^{2}$ Department of Reproductive Health and Research, UNDP, UNFPA, UNICEF, WHO, World Bank Special Programme of Research, Development and Research Training in Human Reproduction, World Health Organization, Geneva, Switzerland. ${ }^{3}$ Institute for Clinical Effectiveness and Health Policy (IECS), Buenos Aires, Argentina.

Received: 7 October 2016 Accepted: 7 October 2016

Published online: 17 October 2016

\section{References}

1. do Carmo Leal M, da Silva AA, Dias MA, da Gama SG, Rattner D, Moreira ME, Filha MM, Domingues RM, Pereira AP, Torres JA, et al. Birth in Brazil: national survey into labour and birth. Reprod Health. 2012;9:15.

2. Brazilian Ministry of Health. SUS Hospital procedures. [Procedimentos hospitalares do SUS] http://tabnet.datasus.gov.br/cgi/deftohtm.exe?sih/cnv/ qiuf.def. In.; 2015. Accessed 12 Jul 2016.

3. Brazilian Ministry of Health, MS/SVS/DASIS: National Data System on Live Births - SINASC [Sistema de Informações de Nascidos Vivos - SINASC] http://tabnet.datasus.gov.br/cgi/deftohtm.exe?sinasc/cnv/nvuf.def. In.; 2016. Accessed 12 Jul 2016.

4. Belizan JM, Althabe F, Cafferata ML. Health consequences of the increasing caesarean section rates. Epidemiology. 2007;18(4):485-6.

5. Kuhle S, Tong OS, Woolcott CG. Association between caesarean section and childhood obesity: a systematic review and meta-analysis. Obes Rev. 2015; 16(4):295-303

6. Lumbiganon P, Laopaiboon M, Gulmezoglu AM, Souza JP, Taneepanichskul S, Ruyan P, Attygalle DE, Shrestha N, Mori R, Nguyen DH, et al. Method of delivery and pregnancy outcomes in Asia: the WHO global survey on maternal and perinatal health 2007-08. Lancet. 2010;375(9713):490-9.

7. Papathoma E, Triga M, Fouzas S, Dimitriou G. Cesarean section delivery and development of food allergy and atopic dermatitis in early childhood. Pediatr Allergy Immunol. 2016;27(4):419-24.

8. Souza JP, Gulmezoglu A, Lumbiganon P, Laopaiboon M, Carroli G, Fawole B, Ruyan P, Maternal WHOGSo, Perinatal Health Research G. Caesarean section without medical indications is associated with an increased risk of adverse short-term maternal outcomes: the 2004-2008 WHO Global Survey on Maternal and Perinatal Health. BMC Medicine. 2010;8:71.

9. World Health Organization. WHO Statement on Caesarean Section Rates WHO/RHR/15.02. In.; 2015.

10. Betran AP, Ye J, Moller AB, Zhang J, Gulmezoglu AM, Torloni MR. The Increasing Trend in Caesarean Section Rates: Global, Regional and National Estimates: 1990-2014. PLoS One. 2016;11(2):e0148343.

11. Potter JE, Hopkins K, Faundes A, Perpetuo I. Women's autonomy and scheduled cesarean sections in Brazil: a cautionary tale. Birth. 2008;35(1): 33-40.

12. Gibbons L, Belizan JM, Lauer JA, Betran AP, Merialdi M, Althabe F. Inequities in the use of cesarean section deliveries in the world. Am J Obstet Gynecol. 2012:206(4):331 e1-19.

13. Rebelo F, Da Rocha CMM, Cortes TR, Dutra CL, Kac G. High cesarean prevalence in a national population-based study in Brazil: The role of private practice. Acta Obstet Gynecol Scand. 2010;89(7):903-8. 
14. Barros AJD, Santos IS, Matijasevich A, Domingues MR, Silveira M, Barros FC, Victora CG. Patterns of deliveries in a Brazilian birth cohort: almost universal cesarean sections for the better-off. Rev Saude Publica. 2011;45(4):635-43.

15. Raifman S, Cunha AJ, Castro MC. Factors associated with high rates of caesarean section in Brazil between 1991 and 2006. Acta Paediatr. 2014; 103(7):e295-299.

16. Hopkins K, de Lima Amaral EF, Mourao AN. The impact of payment source and hospital type on rising cesarean section rates in Brazil, 1998 to 2008. Birth. 2014;41(2):169-77.

17. Nakamura-Pereira M, do Carmo Leal M, Esteves-Pereira AP, Domingues RMS, Torres JA, Dias MAB, Moreira ME: Use of Robson classification to assess cesarean section rate in Brazil: the role of source of payment for childbirth. Reproductive health 2016, 13(Suppl 3). doi:10.1186/s12978-016-0228-7.

18. Domingues RM, Dias MA, Nakamura-Pereira M, Torres JA, d'Orsi E, Pereira AP, Schilithz AO, Carmo Leal M. Process of decision-making regarding the mode of birth in Brazil: from the initial preference of women to the final mode of birth. Cadernos de saude publica. 2014;30 Suppl 1:S1-16.

19. Dias MA, Domingues RMS, Schilithz AOC, Nakamura-Pereira M, do Carmo Leal M: Factors associated with cesarean delivery during labor in primiparous women assisted in the Brazilian Public Health System: Data from a National Survey. Reproductive health 2016, 13(Suppl 3). doi:10.1186/ s12978-016-0231-z

20. Hopkins K. Are Brazilian women really choosing to deliver by cesarean? Soc Sci Med. 2000;51(5):725-40.

21. Weaver JJ, Statham H, Richards M. Are there "unnecessary" cesarean sections? Perceptions of women and obstetricians about cesarean sections for nonclinical indications. Birth. 2007:34(1):32-41.

22. Gamble J, Creedy DK, McCourt C, Weaver J, Beake S. A critique of the literature on women's request for cesarean section. Birth. 2007;34(4):331-40.

23. Kingdon C, Neilson J, Singleton V, Gyte G, Hart A, Gabbay M, Lavender T. Choice and birth method: mixed-method study of caesarean delivery for maternal request. BJOG. 2009;116(7):886-95.

24. Mazzoni A, Althabe F, Liu NH, Bonotti AM, Gibbons L, Sanchez AJ, Belizan JM. Women's preference for caesarean section: a systematic review and meta-analysis of observational studies. BJOG. 2011;118(4):391-9.

25. Steer PJ, Modi N. Elective caesarean sections-risks to the infant. Lancet. 2009:374(9691):675-6.

26. Villar J, Carroli G, Zavaleta N, Donner A, Wojdyla D, Faundes A, Velazco A, Bataglia $V$, Langer A, Narvaez A, et al. Maternal and neonatal individual risks and benefits associated with caesarean delivery: multicentre prospective study. BMJ. 2007;335(7628):1025.

27. Villar J, Valladares E, Wojdyla D, Zavaleta N, Carroli G, Velazco A, Shah A, Campodonico L, Bataglia V, Faundes A, et al. Caesarean delivery rates and pregnancy outcomes: the 2005 WHO global survey on maternal and perinatal health in Latin America. Lancet. 2006; 367(9525):1819-29.

28. Victora CG, Barros FC. Beware: unnecessary caesarean sections may be hazardous. Lancet. 2006:367(9525):1796-7.

29. Belizan JM, Cafferata ML, Althabe F, Buekens P. Risks of patient choice cesarean. Birth. 2006:33(2):167-9.

30. Domingues RMSM, Dias MA, Schilithz AO, do Carmo Leal M: Factors associated with maternal near miss in childbirth and the postpartum period: findings from the Birth in Brazil National Survey, 2011-2012 Reproductive health 2016, 13(Suppl 3): doi:10.1186/s12978-016-0232-y.

31. Bittencourt SDA, Domingues RMSM, Reis LGC, Ramos MM, do Carmo Leal M: Adequacy of public maternal care services in Brazil Reproductive health 2016, 13(Suppl 3). doi:10.1186/s12978-016-0229-6.

32. do Carmo Leal M, Esteves-Pereira AP, Nakamura-Pereira M, Torres JA Theme-Filha M, Domingues RM, Dias MA, Moreira ME, da Gama SG: Prevalence and risk factors related to preterm birth in Brazil. Reproductive health 2016, 13(Suppl 3). doi:10.1186/s12978-016-0230-0.

33. Khan KA, Petrou S, Dritsaki M, Johnson SJ, Manktelow B, Draper ES, Smith LK, Seaton SE, Marlow N, Dorling J, et al. Economic costs associated with moderate and late preterm birth: a prospective population-based study. BJOG. 2015:122(11):1495-505.

34. Lisonkova S, Sabr Y, Butler B, Joseph KS. International comparisons of preterm birth: higher rates of late preterm birth are associated with lower rates of stillbirth and neonatal death. BJOG. 2012;119(13): $1630-9$
35. Moreira ME, Esteves-Pereira AP, Gomes Junior SC, Guinsburg R, Almeida MFB, da Gama SG, do Carmo Leal M: Factors associated with the use of supplemental oxygen or positive pressure ventilation in the delivery room, in infants born with a gestational age $\geq 34$ weeks. Reproductive health 2016, 13(Suppl 3). doi:10.1186/s12978-016-0235-8.

36. World Health Organization, Maternal and Newborn Health/Safe Motherhood Unit: Care in Normal Birth WHO/FRH/MSM/96.24 In.; 1996.

37. do Carmo Leal M, Pereira AP, Domingues RM, Theme Filha MM, Dias MA, Nakamura-Pereira M, Bastos MH, Gama SG. Obstetric interventions during labor and childbirth in Brazilian low-risk women. Cadernos de saude publica. 2014:30:S1-16.

38. da Gama SG, Viellas EF, Torres JA, Bastos MH, Brüggemann OM, Theme Filha MM, Schilithz AO, do Carmo Leal M: Labor and birth care by nurse with midwifery skills in Brazil Reproductive health 2016, 13(Suppl 3). doi:10.1186/s12978-016-0236-7.

39. Torres JA, Domingues RM, Sandall J, Hartz Z, Gama SG, Theme Filha MM, Schilithz AO, Leal Mdo C. Caesarean section and neonatal outcomes in private hospitals in Brazil: comparative study of two different perinatal models of care. Cadernos de saude publica. 2014;30 Suppl 1:S1-12.

40. Baldisserotto ML, Theme Filha MM, da Gama SG: Good practices according to WHO's recommendation for normal labor and birth and women's assessment of the care received: The "Birth in Brazil" National Research Study, 2011/2012. Reproductive health 2016, 13(Suppl 3). doi:10.1186/s12978016-0233-x.

41. World Health Organization: The prevention and elimination of disrespect and abuse during facility-based childbirth WHO/RHR/14.23. In.; 2015.

42. Carvalho LM, Boccolini CS, Oliveira MIC, do Carmo Leal M: The baby-friendly hospital initiative and breastfeeding at birth in Brazil: a cross sectional study Reproductive health 2016, 13(Suppl 3). doi:10.1186/s12978-016-0234-9.

43. Theme Filha MM, Baldisserotto ML, Fraga ACSA, Ayers S, da Gama SG, do Carmo Leal M: Factors associated with unintended pregnancy in Brazil: cross-sectional results from the Birth in Brazil National Survey, 2011/2012. Reproductive health 2016, 13(Suppl 3). doi:10.1186/s12978-016-0227-8.

44. Sedgh $G$, Singh $S$, Hussain R. Intended and unintended pregnancies worldwide in 2012 and recent trends. Stud Fam Plan. 2014:45(3):301-14.

\section{Submit your next manuscript to BioMed Central and we will help you at every step:}

- We accept pre-submission inquiries

- Our selector tool helps you to find the most relevant journal

- We provide round the clock customer support

- Convenient online submission

- Thorough peer review

- Inclusion in PubMed and all major indexing services

- Maximum visibility for your research

Submit your manuscript at www.biomedcentral.com/submit
) Biomed Central 